\title{
The origin of the Canary Island Seamount Province - New ages of old seamounts
}

SUBJECT AREAS:

VOLCANOLOGY

GEODYNAMICS

PALAEOCEANOGRAPHY

GEOLOGY

Received

9 April 2013

Accepted

13 June 2013

Published

1 July 2013

\section{Correspondence and} requests for materials should be addressed to

P.B. (pbogaard@ geomar.de)

\author{
Paul van den Bogaard
}

GEOMAR Helmholtz Centre for Ocean Research Kiel Wischhofstr. 1-3, D-24148 Kiel, Germany.

The Canary Island Seamount Province forms a scattered hotspot track on the Atlantic ocean floor $\sim 1300 \mathrm{~km}$ long and $\sim 350 \mathrm{~km}$ wide, perpendicular to lithospheric fractures, and parallel to the NW African continental margin. New ${ }^{40} \mathrm{Ar} /{ }^{39} \mathrm{Ar}$ datings show that seamount ages vary from $133 \mathrm{Ma}$ to $0.2 \mathrm{Ma}$ in the central archipelago, and from $142 \mathrm{Ma}$ to $91 \mathrm{Ma}$ in the southwest. Combining ${ }^{40} \mathrm{Ar} /{ }^{39} \mathrm{Ar}$ ages with plate tectonic reconstructions, I find that the temporal and spatial distribution of seamounts is irreconcilable with a deep fixed mantle plume origin, or derivation from passive mantle upwelling beneath a mid-ocean ridge. I conclude that shallow mantle upwelling beneath the Atlantic Ocean basin off the NW African continental lithosphere flanks produced recurrent melting anomalies and seamounts from the Late Jurassic to Recent, nominating the Canary Island Seamount Province as oldest hotspot track in the Atlantic Ocean, and most long-lived preserved on earth.

T he Canary Island Seamount Province (CISP) comprises more than 100 seamounts, isolated volcanic structures on the seafloor ranging from small $(<1000 \mathrm{~m}$ height) to mid-sized $(>1000 \mathrm{~m})$ and mid-sized explosive ( $<700 \mathrm{~m}$ water depth) to ocean islands ${ }^{1}$. It represents the easiest hotspot track to find in the northern part of the African plate ${ }^{2}$, but its location is difficult to explain, and its origin is controversial ${ }^{3-6}$. Primitive CISP basalts are derived from decompression melting of upwelling mantle that includes deep (HIMU-type), depleted (DMM-type), and enriched (EM-type) mantle components ${ }^{7-9}$ and erupt after limited interaction with altered MORB crust and Cenozoic sediments ${ }^{10}$. Plausible models for the formation of scattered seamount chains like the CISP include (a) deep mantle upwelling through fixed mantle plumes ${ }^{5}$, (b) shallow passive mantle upwelling beneath mid-ocean ridges ${ }^{11}$ and (c) shallow mantle convection from continental lithosphere flanks ${ }^{3}$.

Original fixed-plume models ${ }^{5}$ were based on the E-W alignment and apparent age progression of the Canary Islands from Lanzarote-Fuerteventura (15-23 $\mathrm{Ma}^{12}$ ) to El Hierro ( $\left.<1.1 \mathrm{Ma}^{13}\right)$ (Fig. 1), and the assumptions that Canarian island-seamounts grow fast, and that their subaerial ages were representative of the onset of magma generation and mantle upwelling at any given site. Later studies included northeastern seamounts, and inferred a wider NE-SW-oriented fixed-plume track ${ }^{4}$ beginning near Essaouira Seamount $(68 \mathrm{Ma})$ and ending around El Hierro and La Palma $\left(<4 \mathrm{Ma}^{14}\right)$. Because the continental margin, palaeomagnetic anomalies and MORs, and plate motion vector run roughly parallel, a NE-SW oriented seamount chain appears compatible with either model, but the age distribution and geotectonic setting are critical. Here we look at the ages of CISP seamounts from the central archipelago to the SW, analyzing rock samples that were dredged during RV Meteor cruise $M 43^{15}$. For the first time, seamount age data across the entire CISP are available for consideration, and based on the spatial and temporal distribution, mantle convection models of origin can be evaluated. ${ }^{40} \mathrm{Ar} r{ }^{39} \mathrm{Ar}$ analyses were carried out by single-crystal laser fusion and laser step-heating using irradiation monitor TCR $\left(27.87 \mathrm{Ma}^{16}\right)$. I start with a summary of results, from northeast to southwest (2Sigma errors).

\section{Results}

Canary ridge. This seamount is part of the ridge connecting the seamount socles of Gran Canaria and Fuerteventura (Fig. 1), and yields a hornblende mean age of $17.8 \pm 0.3 \mathrm{Ma}$ and a matrix step-heating plateau age of $17.7 \pm 0.2 \mathrm{Ma}$ (Fig. 2). Note, this is $\sim 3 \mathrm{~m}$.y. older than the oldest subaerial "shield-stage" lavas of overlying Gran Canaria $\left(\sim 15 \mathrm{Ma}^{17}\right)$.

El hijo. A $600 \mathrm{~m}$ high young seamount ${ }^{15}$ lies in the channel between Gran Canaria and Tenerife. Biotite phenocrysts of its trachyandesite lava samples 755-1 and 759-3 yield a weighted mean age of $0.24 \pm 0.02 \mathrm{Ma}$ (Fig. 2). 


\section{Longitude}

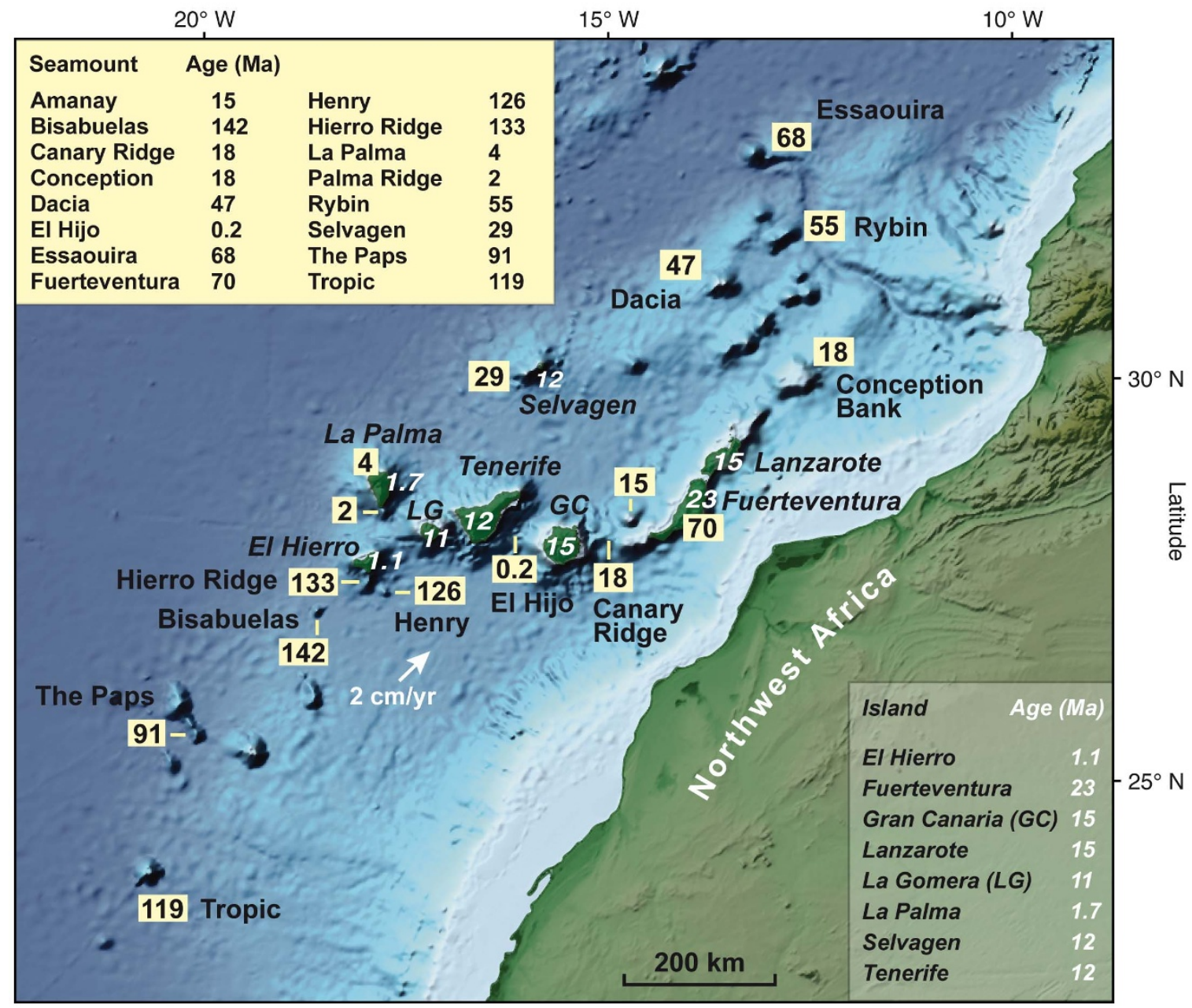

Figure $1 \mid$ Topographic map of the NW African continental margin and age distribution in the Canary Island Seamount Province (CISP). Numbers are the oldest ages determined for seamounts and islands in millions of years. Seamount ages from this study plus additional data for Henry ${ }^{29}$, La Palma ${ }^{14}$, Fuerteventura $^{24-26}$, Amanay ${ }^{34}$, Selvagen, Conception, Dacia, Rybin, and Essaouira seamounts ${ }^{4,8}$. Oldest subaerial island ages (white) for Lanzarote and Fuerteventura $^{12}$, Gran Canaria ${ }^{17}$, Tenerife ${ }^{10}$, La Gomera ${ }^{35}$, La Palma ${ }^{18}$, El Hierro ${ }^{13}$, and Selvagen ${ }^{8}$. Map base from NOAA (ETOPO1) ${ }^{36}$. Present plate motion vector from UNAVCO model (http://www.unavco.org).

Palma ridge. This seamount is in the southern submarine flanks of La Palma. Biotites from phonolite lava 666-2 yield a mean age of 2.11 $\pm 0.03 \mathrm{Ma}$, younger than the uplifted seamount series of northern La Palma ( $\leq 4 \mathrm{Ma}^{14}$ ) but older than the subaerial volcanics of the island $\left(<1.7 \mathrm{Ma}^{18}\right)$. There is a Pliocene evolved seamount in the submarine structure of southern La Palma.

Hierro ridge. In the flanks of El Hierro, a seamount ridge extends $\sim 30 \mathrm{~km}$ south. Its trachyte breccia sample 678-2 yields a mean Kfeldspar age of $133.3 \pm 0.2 \mathrm{Ma}$, reproduced by a mean hornblende age of 133.8 $\pm 0.6 \mathrm{Ma}$. The submarine structure of El Hierro includes an Early Cretaceous seamount, overlain by later El Hierro volcanics at its northern flank.

Bisabuelas. A small group of seamounts located $70 \mathrm{Km}$ southwest of El Hierro was named "Las Hijas" (The Daughters) and suspected to represent juvenile future Canary Islands ${ }^{19}$. Eight plagioclase single-crystal analyses of its trachyte sample 689-2 yield a mean age of $140.5 \pm 0.7 \mathrm{Ma}$. Nine plagioclase crystals from trachyte sample 689-5 yield a mean age of $141.7 \pm 0.4 \mathrm{Ma}$. This is probably the oldest seamount in the Atlantic Ocean. Whether its origin is Early Cretaceous or Late Jurassic depends on the age of the submerged seamount structure, which is likely a few million years older than $142 \mathrm{Ma}$, and uncertainties of the Jurassic-Cretaceous chronostratigraphic boundary (e.g. $142 \pm 2 \mathrm{Ma}^{20}$ ). Bisabuelas (Great-grandmothers) is suggested as an alternative provisional name for this seamount group.

The paps. This seamount group is located $\sim 300 \mathrm{~km}$ southwest of El Hierro. K-feldspar microphenocrysts from trachyphonolitic pumice breccia 706-1 yield a step-heating age spectrum with disturbances in the low- and high-temperature regions, indicating partial alteration (Fig. 2). The plateau in-between comprises $>52 \%$ of the ${ }^{39} \mathrm{Ar}$ released and yields a plateau age of $91.1 \pm 0.2 \mathrm{Ma}$.

Tropic. Tropic seamount is at the southwestern edge of the CISP. Thirteen K-feldspar phenocrysts from basal sample 699-1 yield a mean age of $119.3 \pm 0.3 \mathrm{Ma}$. Seven plagioclase crystals from topmost trachyte sample 693-2 yield a mean age of $115.6 \pm$ $0.5 \mathrm{Ma}$. Twentythree anorthoclase phenocrysts from trachyte sample 692-3 yield a mean age of $116.3 \pm 0.2 \mathrm{Ma}$, reproduced by 10 hornblende analyses $(116.6 \pm 0.5 \mathrm{Ma})$, and matrix step-heating yields a plateau age of $113.9 \pm 0.2 \mathrm{Ma}$ for basalt sample 692-1. All samples are from the southwestern slopes and all ages are 


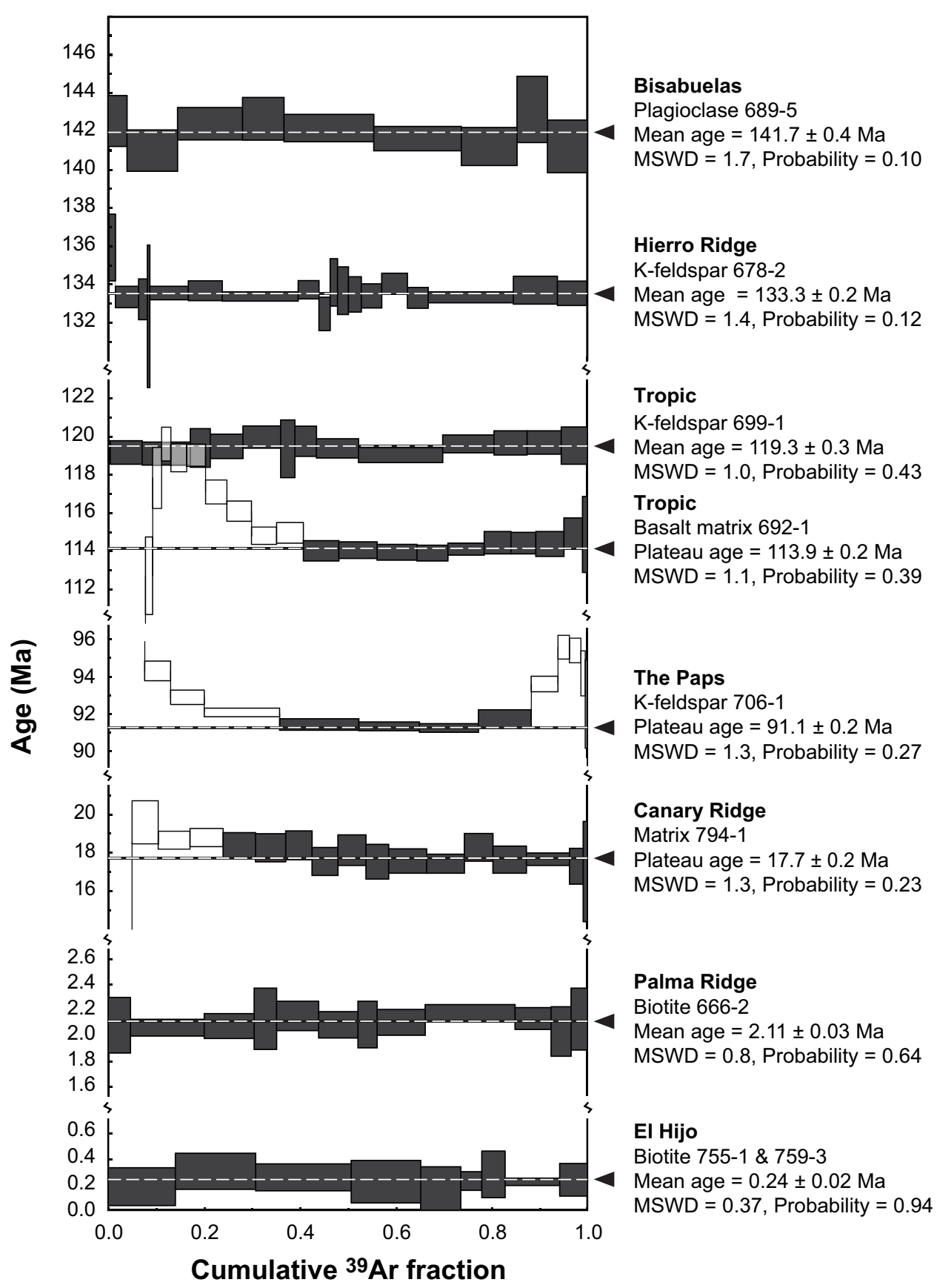

Figure 2 142 million years of Canarian seamount volcanism in ${ }^{40} \mathrm{Ar} /{ }^{39} \mathrm{Ar}$ age spectra. Apparent ages from sequential single-crystal total fusions and step-heating analyses are plotted against cumulative ${ }^{39} \mathrm{Ar}$ fractions. Accepted analyses and plateau steps are black. Box heights are $\pm 2 \sigma$. Inversevariance weighted mean ages are statistically valid, as indicated by low Mean Square Weighted Deviates (MSWD) and sufficient Probabilities $(>0.05)^{37,38}$. Mean age errors are $2 \sigma$ and include uncertainties in J-values. Note breaks in age scale. See text and Supplementary Information S3 and S4 for more data and diagrams.

significantly higher than plagioclase K-Ar ages from the northern slope (84 to $59 \mathrm{Ma}^{21}$ ). Tropic Seamount erupted from $119 \mathrm{Ma}$ to $114 \mathrm{Ma}$ with possible late stage eruptions until $\sim 60 \mathrm{Ma}$.

\section{Discussion}

Depending on the rate, duration and frequency of magma supply from melting anomalies, and the age and depth of origin, Canary seamounts grow from the Late Jurassic to Recent ocean floor towards or beyond sea level. The bulk thickness of sediments covering the basaltic oceanic crust basement ( $\sim 155 \mathrm{Ma}$ old around palaeo-magnetic anomaly $\mathrm{M} 25^{22}$ ) is known from reflection seismics as at least
2,500-3,000 m, e.g. NE of Tenerife and SE of El Hierro ${ }^{23}$. At ages up to $142 \mathrm{Ma}$, Canarian seamounts are partly burried in this sedimentary sequence. Consequently, many seamounts are much larger than meets the eye or remote sensors, and subaerial, submarine and subsedimentary sections need to be considered to constrain seamount dimensions and to understand structural relationships. Two examples (Fig. 3):

Bisabuleas seamount rises to 2850 m.b.s.l. above the seafloor, which levels at $\sim 3850$ m.b.s.l. in the vicinity. Considering that $\sim 3,000$ m of sediment were deposited on the sea floor and seamount flanks from $142 \mathrm{Ma}$ to recent, Bisabuelas seamount must be at least $4,000 \mathrm{~m}$ tall, and only a quarter is peeking out of the sediment. 


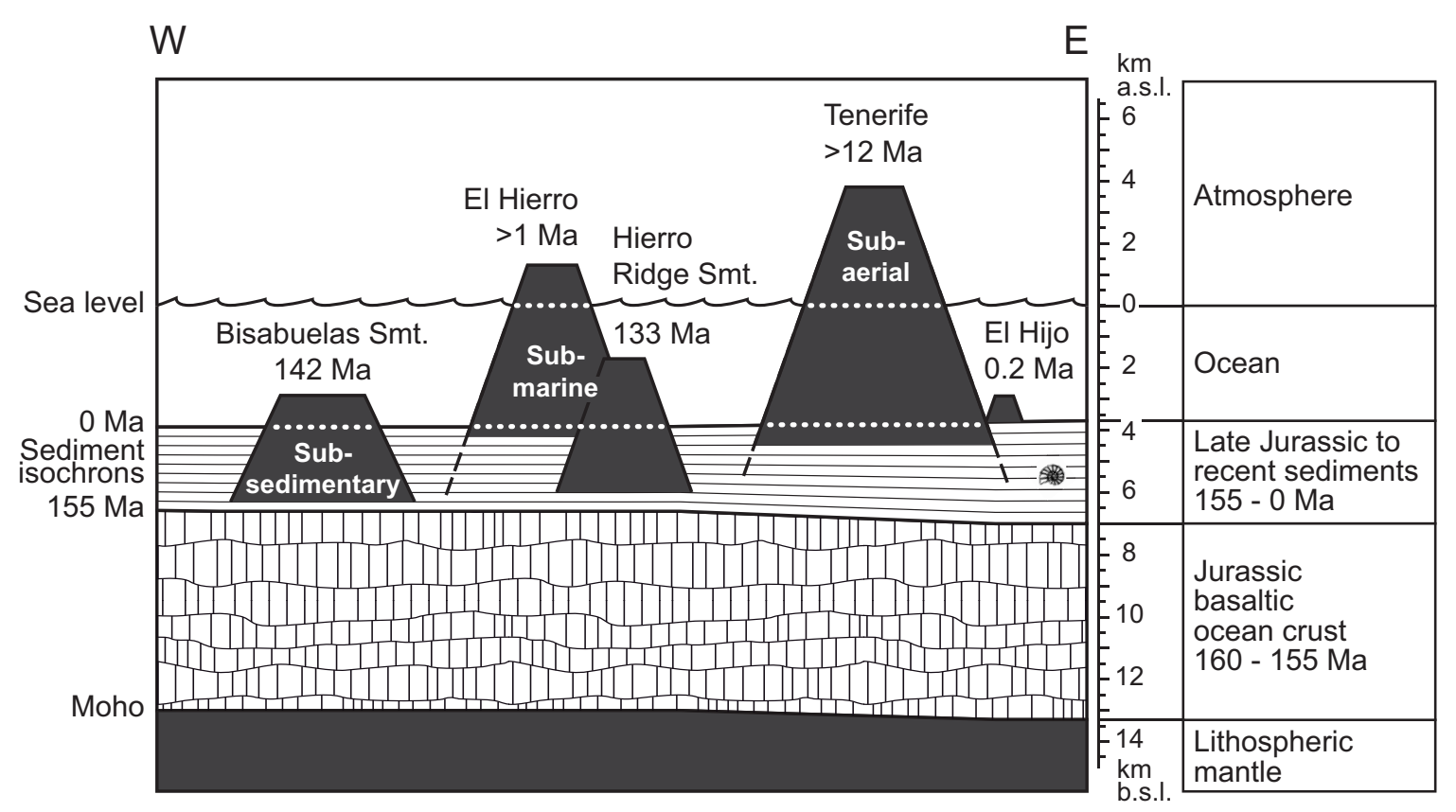

Figure 3 Schematic cross section of selected seamount settings. Thickness and depth of basaltic ocean crust $\left(\sim 155 \mathrm{Ma}\right.$ around anomaly M25 $\left.5^{22}\right)$ and bulk thickness and depth of sediments from reflection seismics ${ }^{23,27}$. Sediment isochrons (155 to $0 \mathrm{Ma}$ ) schematically. To keep it simple, seamount subsidence due to lithosphere loading, magmatic plumbing systems, and interlocking of seamount clastic aprons and sediment sequence are not considered in this sketch. Subaerial and submarine seamount heights are precise, subsedimentary seamount heights are minimum estimates, especially for Tenerife. See text for discussion.

El Hierro, the second example, rises to 1,500 m.a.s.l. from $\sim 3,900$ m.b.s.l. In addition, Hierro Ridge seamount reaches from 1500 m.b.s.l. down to at least 6,000 m.b.s.l., estimating $\sim 2,500 \mathrm{~m}$ of sediment since the Early Cretaceous. Accepting Hierro Ridge as integral part of El Hierro's seamount sub-structure, 2,500 $\mathrm{m}$ subsedimentary height add to the submarine-subaerial height of 5,400 m, transforming the youngest and smallest Canary Island into one of the oldest $(>133 \mathrm{Ma})$ and tallest $(>7,900 \mathrm{~m})$ Canary Island seamounts.

The new ${ }^{40} \mathrm{Ar} /{ }^{39} \mathrm{Ar}$ dates provide evidence for both a much prolongued history of the CISP and of individual seamounts, and for a composite structure and multi-stage origin of subaerially young and supposedly fast-grown ${ }^{13}$ islands. The riddle of Miocene to

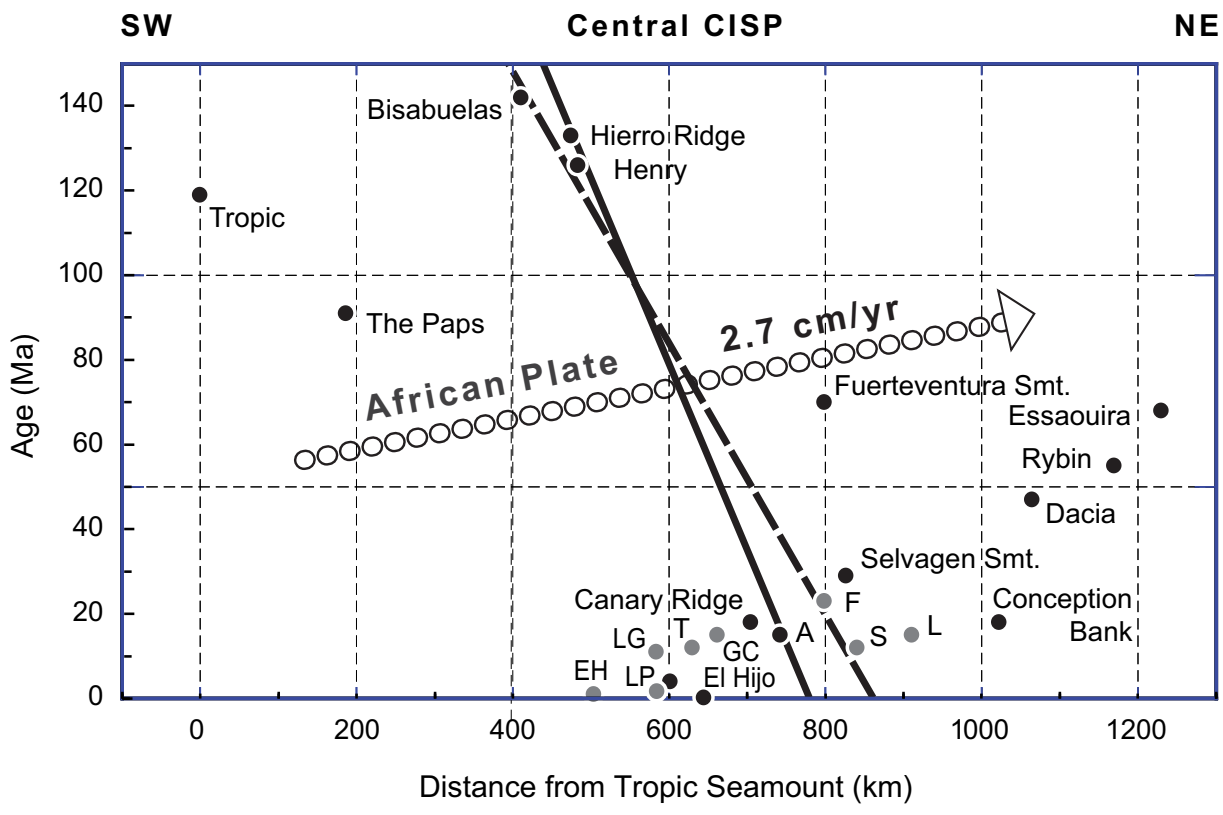

Figure $4 \mid$ No proper age progression in the CISP. Oldest ages of seamounts (black) and islands (grey) versus distance from Tropic Seamount along a SW-NE transect. Dotted line indicates average vector of the African Plate during the past 100 m.y. Seamount distribution should be aligned parallel to this vector (youngest in the SW, oldest in the NE) if derived from a fixed plume. Naive linear regression attempts yield poor solutions for the seamount data set (dashed line, $\mathrm{R}^{2}=0.20$ ) and data set including subaerial island data (solid line, $\mathrm{R}^{2}=0.13$ ), indicating a scattered age distribution, and lack of a significant and systematic age progression. $\mathrm{A}=$ Amanay Smt., $\mathrm{EH}=\mathrm{El}$ Hierro, $\mathrm{LP}=\mathrm{La}$ Palma, $\mathrm{LG}=\mathrm{La}$ Gomera, $\mathrm{T}=\mathrm{Tenerife}, \mathrm{GC}=\mathrm{Gran}$ Canaria, F = Fuerteventura, $S=$ Selvagen, $L=$ Lanzarote (for additional age data sources see Fig. 1). 


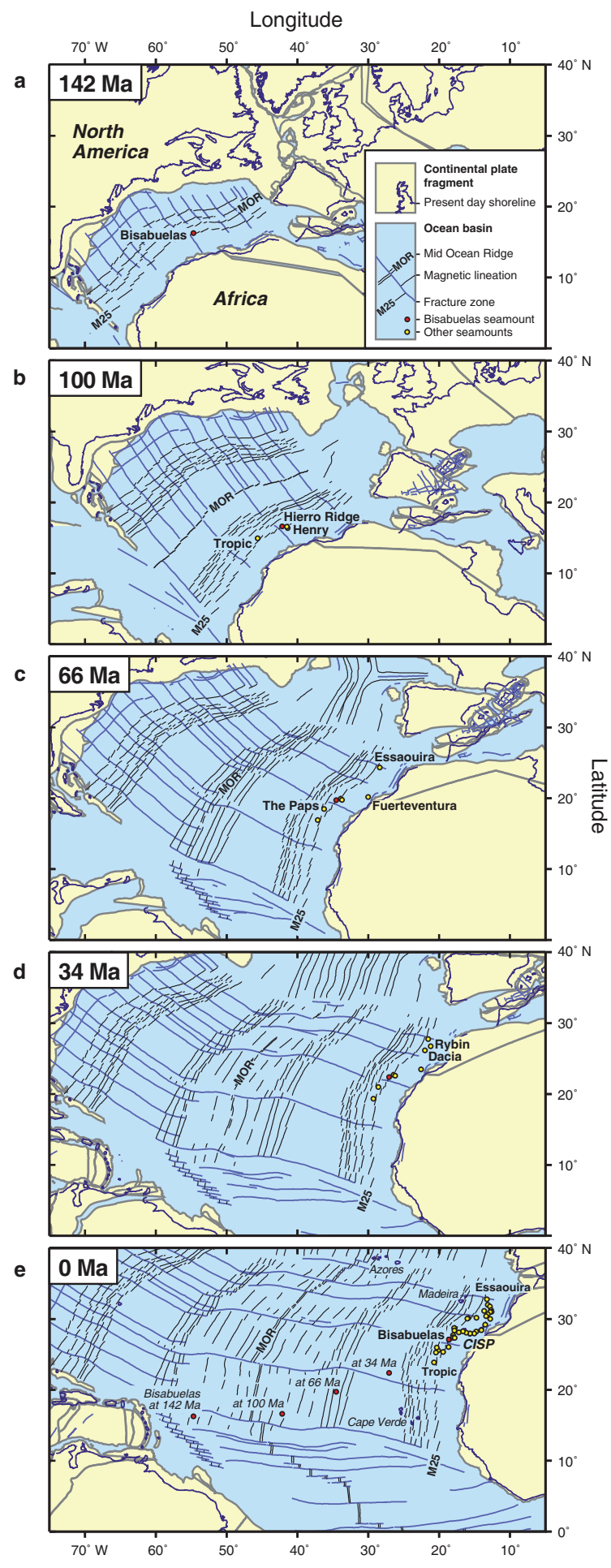

Figure $5 \mid$ Mantle upwelling and CISP follow the NW African continental margin. (a-e), Plate tectonic reconstructions and setting of CISP seamounts at $142 \mathrm{Ma} \mathrm{(a),} 100 \mathrm{Ma}$ (b), $66 \mathrm{Ma}$ (c, K-Pg boundary), $34 \mathrm{Ma}$ (d), and Present (e). Maps created by the author with ODSN Advanced Plate Tectonic Reconstructions (http://www.odsn.de) The reconstructions show that the CISP started to form near palaeomagnetic anomaly M25 no later that 142 m.y. ago, when the North American and African continents were only $900 \mathrm{~km}$ apart (a). With the African Plate (continent plus new ocean crust) drifting primarily eastward, the MOR veering away to the NW and the North Central Atlantic opening up, more seamounts erupted at equal distance from the rifted NW African continental margin, scattered along palaeomagnetic anomaly M25 (b-c). At the latest from the K-Pg boundary (c) the outlines of the CISP have not changed significantly. Later seamounts fill up the space between Tropic and Essaouira (d). Figure (e) shows the present spatial distribution of all large seamounts in the CISP, including islands and unnamed and undated ones (see Fig. 1 for details). Future studies will show how many of these are actually much older, and should really be plotted in $(a-d)$. The coordinates of Bisabuelas Seamount, as projected from (a-d) onto (e), illustrate the path taken by the African plate (central CISP range) from $142 \mathrm{Ma}$ to Present. This is what a hotspot track should look like, if a deep fixed-plume mantle upwelling had ever existed beneath the central CISP at $142 \mathrm{Ma}$ or later. Instead, mantle upwelling and CISP follow the African plate on its $3000 \mathrm{~km}$ journey to the E-NE, indicating that mantle convection is causally related and physically connected to the moving plate, its continental lithospheric roots respectively. 
Pleistocene islands in the center of an essentially Cretaceous seamount field (Fig. 1) may have a simple answer: Only the subaerial island tips of these giant seamounts are young, their seamount roots can be Early Cretaceous or older. As yet, only a few seamount substructures were revealed, however, by falling sea levels (Selvagen: $>29 \mathrm{Ma}^{8}$ ), by tectonic uplift (Fuerteventura: $>70 \mathrm{Ma}^{24-26}$ ) or by dredging (El Hierro: $>133 \mathrm{Ma}$ ). The proof of widespread Late Jurassic to Mid Cretaceous seamount volcanism in the CISP has significant consequences for seismic and sedimentary facies models ${ }^{27}$ and mantle convection models, which were based on an initiation of CISP volcanism and supply of volcanic sediments to basins in the Late Cretaceous to Early Paleogene.

An age progression from the SW to the NE is conditio sine qua non for a fixed-plume origin of the CISP, given that the African plate moves to the $\mathrm{NE}^{1,4,28}$. The new ${ }^{40} \mathrm{Ar} /{ }^{39} \mathrm{Ar}$ ages show that seamounts do not grow systematically older from the southwest (Tropic, $119 \mathrm{Ma}$ ) to the northeast (Essaouira, 68 Ma) (Fig. 1). Canarian seamounts are "old" in the southwestern, "old and young" in the central and "intermediate" in the northeastern province (Fig. 4). Even if the African plate had moved in reverse, this would not constitute an appropriate age progression. The temporal and spatial distribution of Canary seamounts is irreconcilable with single fixed-plume models.

Shallow recycling of continental lithosphere into passively upwelling mantle beneath mid-ocean ridges can explain the origin of diffuse seamount chains in young ocean basins when seamount formation closely follows an $\mathrm{MOR}^{11}$. Plate tectonic reconstructions show, however, that the Atlantic MOR veers away orthogonally from the CISP. When Bisabuelas erupted, the MOR was already $\sim 200 \mathrm{~km}$ away and the seamount erupted on an ocean floor $>10$ m.y. older than the seamount (palaeomagnetic anomaly M25) (Fig. 5). Still during the Early Cretaceous, at least three more large seamounts erupted to the east and west (Hierro Ridge $133 \mathrm{Ma}$, Henry $126 \mathrm{Ma}^{29}$, Tropic $119 \mathrm{Ma}$ ). By the K-Pg boundary the latest, the CISP had reached its present dimensions with eruptions from The Paps (91 Ma), Fuerteventura (>70 Ma), and Essaouira (68 Ma), but the MOR had veered another 1,200 km to the NW (Fig. 5). An origin of the entire CISP from passive mantle upwelling beneath the midAtlantic ridge is also not reasonable.

Of the three competing mantle convection models ${ }^{1,3,11}$, only shallow mantle convection at the rifted continental lithosphere flanks can explain the alignment, age distribution, plate tectonic setting and long history of individual centers of the CISP, and agrees with the observed mix $^{7-10}$ of geochemical mantle components. Breakup of the Pangaean continent exposed $>250 \mathrm{~km}$ thick cratonic lithosphere to hot asthenospheric mantle and caused mantle upwelling (edge-driven convection $)^{3}$ beneath the juvenile ocean crust (MORB) and recycling of subcontinental lithosphere (EM-type mantle). Seamount formation started less than 40 m.y. after the earliest rifting in the North Central Atlantic $\left(\sim 184 \mathrm{Ma}^{25}\right)$, when ocean crust formation was barely advanced (i.e. the process producing depleted DMMtype mantle) and HIMU-type mantle components were ambiant to dominant in the asthenosphere beneath the young Atlantic ocean basin and lithosphere.

While the origin of the entire CISP from shallow plate-bound mantle convection off the rifted NW African continental margin is fully compatible with the geochemical composition, spread and age of seamounts, and plate tectonic reconstructions, the present data set does not rule out the possibility of more complex scenarios such as alternating mantle plume and plate-related convection analogue to the Samoan hotspot system ${ }^{30}$, or multiple, successive, mantle plumes similar to "hot spot highways" in the Pacific ${ }^{31}$. Even hybrid models combining early passive mantle upwelling near the MOR in the Late Jurassic with shallow edge-driven convection throughout the Cretaceous and the appearance of a single deep-fixed plume in the Early Paleogene are imaginable. Prerequisites, however, to explain the origin of the CISP and the temporal and spatial distribution of its seamounts, these scenarios are not.

The conditions of formation of CISP-type seamount chains (shallow source, juvenile astenosphere, slow plate, low production rate ${ }^{32}$, recurrent mantle upwelling and melting anomalies beneath the same plate segment) are fundamentally different from fixed-plume prototypes like the Hawaii-Emperor chain (deep source, mature astenosphere, high production rate, fast plate, rapid decoupling of melting anomalies from upwelling source $)^{33}$, yet seamount dimensions are comparable. I conclude that plate-bound shallow mantle convection is an important mechanism of seamount formation in young ocean basins bordered by rifted continental margins, and is capable of sustaining extremely long-lived hotspot tracks, for at least 142 m.y. in case of the Canary Island Seamount Province.

\section{Methods}

16 mineral and matrix separates from 12 dredged rock samples from RV Meteor cruise M43 were analyzed by ${ }^{40} \mathrm{Ar} /{ }^{39} \mathrm{Ar}$ laser step-heating and single-crystal fusion. Crystals (plagioclase, K-feldspar, hornblende, biotite) and matrix particles were hand-picked from crushed and sieved rock splits $(250-500 \mu \mathrm{m})$. To remove alteration surfaces and adhering matrix material, feldspar separates were etched in 15\% hydrofluoric acid for 5 minutes. All samples were washed and cleaned using an ultrasonic disintegrator. Separates were irradiated in aluminum trays and cans lined by cadmium foil at the 5-MW reactor of the GKSS Research Center (Helmholtz Centre Geesthacht, Germany). The neutron flux was monitored using Taylor Creek Rhyolite Sanidine $\left(27.87 \pm 0.04 \mathrm{Ma}^{16}\right) .{ }^{40} \mathrm{Ar} /{ }^{39} \mathrm{Ar}$ laser analyses were carried out at the GEOMAR Geochronology Lab using a 20 W SpectraPhysics Argon-Ion laser and an MAP 216 series noble gas mass spectrometer. Ar Isotope ratios from mass spectrometry were corrected for mass discrimination, background and blank values, J-value gradients, and interfering neutron reactions on $\mathrm{Ca}$ and $\mathrm{K}$.

The step-heating and single-crystal data are evaluated in age spectra (apparent age and error vs. cumulative ${ }^{39} \mathrm{Ar}$ in order of analysis) trying to detect plateaus ( $>3$ consecutive steps comprising $>50 \%$ of the ${ }^{39} \mathrm{Ar}$ released, with ages overlapping within 2Sigma errors), and single-crystal populations with ages overlapping within 2Sigma errors. Plateau ages represent the inverse-variance weighted mean of the plateau step ages and errors. Statistical validity of mean ages are tested by calculating the MSWD (mean square weighted deviates) and POF (probability of fit; should be $>0.05$ at 2 Sigma/95\% confidence levels) ${ }^{37}$. Because marine rock samples are generally variably altered, the degree of alteration is monitored via alteration indices based on the measured ${ }^{36} \mathrm{Ar} /{ }^{37} \mathrm{Ar}$ ratios (plagioclase, hornblende, matrix) or measured ${ }^{36} \mathrm{Ar} /{ }^{39} \mathrm{Ar}$ ratios (K-feldspar, Biotite) following established methods ${ }^{38}$. Low-temperature heating steps generally yield 10 to 100 times higher alteration indices, but are not included in the plateau age calculations. Few crystals that yield deviating apparent ages and alteration indices are also excluded from the single-crystal mean age calculations. Results are summarized in Supplement Table S2. Full analytical data are given in Supplement Table S3. Isotope correlation diagrams, age spectra, $\mathrm{Ca} / \mathrm{K}$ ratios and atmospheric ${ }^{40}$ Ar contents are shown in Supplement Figures S4.

1. Staudigel, H. \& Clague, D. A. The geological history of deep-sea volcanoes. Biosphere, hydrosphere, and lithosphere interactions. Oceanography 23, 58-71 (2010).

2. Morgan, J. W. \& Morgan, J. P. in Plates, Plumes, and Planetary Processes (eds Foulger, G. \& Jurdy, D. M.) GSA special paper 430, 65-78 (2007).

3. King, S. D. \& Ritsema, J. African hot spot volcanism: small-scale convection in the upper mantle beneath cratons. Science 290, 1137-1140 (2000).

4. Geldmacher, J., Hoernle, K. A., van den Bogaard, P., Duggen, S. \& Werner, R. New ${ }^{40} \mathrm{Ar} /{ }^{39} / \mathrm{Ar}$ age and geochemical data from seamounts in the Canary and Madeira volcanic provinces: Support for mantle plume hypothesis. Earth Planet. Sci. Lett. 237, 85-101 (2005).

5. Morgan, W. J. Hot spot tracks and the early rifting of the Atlantic. Tectonophysics 94, 123-139 (1983)

6. Carracedo, J. C. et al. Hotspot volcanism close to a passive Continental margin: the Canary Islands. Geol. Mag. 135, 591-604 (1998).

7. Hoernle, K. A., Tilton, G. \& Schmincke, H. U. The Sr-Nd-Pb isotopic evolution of Gran Canaria: Evidence for shallow enriched mantle beneath the Canary Islands. Earth Planet. Sci. Lett. 106, 44-63 (1991).

8. Geldmacher, J., Hoernle, K. A., van den Bogaard, P., Zankl, G. \& GarbeSchönberg, D. Earlier history of the $>70$-Ma-old Canary hotspot based on the temporal and geochemical evolution of the Selvagen Archipelago and neighboring seamounts in the eastern North Atlantic. J. Volcanol. Geotherm. Res. 111, 55-87 (2001).

9. Gurenko, A. A., Sobolev, A. V., Hoernle, K. A., Hauff, F. \& Schmincke, H. U. Source components of the Gran Canaria (Canary Islands) shield stage magmas: evidence from olivine composition and $\mathrm{Sr}-\mathrm{Nd}-\mathrm{Pb}$ isotopes. Contrib. Mineral. Petrol. 159, 689-702 (2010). 
10. Thirlwall, M. F., Jenkins, C., Vroon, P. Z. \& Mattey, D. P. Crustal interaction during construction of oceanic islands: $\mathrm{Pb}-\mathrm{Sr}-\mathrm{Nd}-\mathrm{O}$ isotope geochemistry of the shield basalts of Gran Canaria, Canary islands. Chem. Geol. 135, 233-262 (1997).

11. Hoernle, K. et al. Origin of Indian Ocean seamount province by shallow recycling of continental lithosphere. Nature Geosci. 4, 883-887 (2011).

12. Coello, J. et al. Evolution of the eastern volcanic ridge of the Canary Islands based on new K-Ar data. J. Volcanol. Geotherm. Res. 53, 251-274 (1992)

13. Guillou, H., Carracedo, J. C., Perez Torrado, F. \& Rodriguez Badiola, E. K-Ar ages and magnetic stratigraphy of a hotspot-induced, fast grown oceanic island: El Hierro, Canary Islands. J. Volcanol. Geotherm. Res. 73, 141-155 (1996).

14. Staudigel, H., Feraud, G. \& Giannerini, G. The history of intrusive activity on the island of La Palma (Canary Islands). J. Volcanol. Geotherm. Res. 27, 299-322 (1986).

15. Schmincke, H. U. \& Graf, G. DECOS/OMEX II, Cruise No. 43, 25 November 1998-17 January 1999. Meteor Reports, 2000-1 (Univ. Hamburg), 1-99 (2000)

16. Lanphere, M. A. \& Dalrymple, G. B. First-principles calibration of ${ }^{38}$ Ar tracers implications for the ages of ${ }^{40} \mathrm{Ar} /{ }^{39} \mathrm{Ar}$ fluence monitors. U. S. Geological Survey Prof. Paper 1621, p. 10 (2000).

17. van den Bogaard, P. \& Schmincke, H. U. in Proceedings ODP Scientific Results 157 (eds Weaver, P. P. E., Schmincke, H. U., Firth, J. V. \& Duffield, W. A.) 127-140 (College Station, 1998).

18. Guillou, H., Carracedo, J. C. \& Duncan, R. A. K-Ar, ${ }^{40} \mathrm{Ar} /{ }^{39} \mathrm{Ar}$ ages and magnetostratigraphy of Brunnes and Matuyama lava sequences from La Palma Island. J. Volcanol. Geotherm. Res. 106, 175-194 (2001)

19. Rihm, R., Jacobs, C. L., Krastel, S., Schmincke, H. U. \& Alibes, B. Las Hijas Seamounts - the next Canary Islands? Terra Nova 10, 121-125 (1998).

20. Bralower, J. J., Ludwig, K. R., Obradovich, J. D. \& Jones, V. Berriasian (Early Creatceous) radiometric ages for the Grindstone Creek section, Sacramento Valley, California. Earth Planet. Sci. Lett. 98, 62-73 (1990).

21. Blum, N., Halbach, P., Münch, U. \& van Gerven, M. Pb-Sr-Nd Isotopic Data of Mesozoic Ocean Island Basalts from the Eastern Atlantic Ocean Continental Margin. Chem. Erde 56, 193-205 (1996).

22. Müller, R. D., Roest, W. R., Royer, J.-Y., Gahagan, L. M. \& Sclater, J. G. Digital isochrons of the world's ocean floor. J. Geophys. Res. 102, 3211-3214 (1997).

23. Watts, A. B. et al. A seismic study of lithospheric flexure in the vicinity of Tenerife, Canary Islands. Earth Planet. Sci. Lett. 146, 431-447 (1997).

24. Le Bas, M. J., Rex, D. C. \& Stillman, C. J. The early magmatic chronology of Fuerteventura, Canary Islands. Geol. Mag. 123, 287-298 (1986).

25. Steiner, C., Hobson, A., Favre, P. \& Stampli, G. M. Early Jurassic sea-floor spreading in the central Atlantic - The Jurassic sequence of Fuerteventura (Canary Islands). Geol. Soc. Am. Bull. 110, 1304-1317 (1998).

26. Balogh, K., Ahijado, A., Casillas, R. \& Fernandez, C. Contribution to the chronology of the Basal Complex of Fuerteventura, Canary Islands. J. Volcanol. Geotherm. Res. 90, 81-101 (1999).

27. Collier, J. S. \& Watts, A. B. Lithospheric response to volcanic loading by the Canary Islands: constraints from seismic reflection data in their flexural moat. Geophys. J. Int. 147, 660-676 (2001).
28. Duncan, R. A. Hotspots in the southern oceans - An absolute frame of reference for motion of the Gondwana continents. Tectonophysics 74, 29-42 (1981).

29. Klügel, A., Hansteen, T. H., van den Bogaard, P., Strauss, H. \& Hauff, F. Holocene fluid venting at an extinct Cretaceous seamount, Canary archipelago. Geology 39, 855-858 (2011).

30. Koppers, A. A. P. et al. Age systematics of two young en echelon Samoan volcanic trails. Geochem. Geophys. Geosyst. 12, 1-40 (2011) Q07025, doi:10.1029/ 2010GC003438.

31. Jackson, M. G. et al. Samoan hot spot track on a "hot spot highway": Implications for mantle plumes and a deep Samoan mantle source. Geochem. Geophys. Geosyst. 11, 1-24 (2010) Q12009, doi:10.1029/2010GC003232.

32. Ancochea, E. et al. Constructive and destructive episodes in the building of a young oceanic Island, La Palma, Canary Islands, and genesis of the Caldera de Taburiente. J. Volcanol. Geotherm. Res. 60, 243-262 (1994).

33. Coombs, M. L., Eakins, B. W. \& Cervelli, P. F. Growth and collapse of Hawaiian Volcanoes. J. Volcanol. Geotherm. Res. 151, 1-318 (2006).

34. Ancochea, E. \& Huertas, M. J. Age and composition of the Amanay Seamount, Canary Islands. Marine Geophys. Res. 24, 161-169 (2003).

35. Ancochea, E., Hernan, F., Huertas, M. J., Brändle, J. L. \& Herrera, R. A new chronostratigraphical and evolutionary model for La Gomera: implications for the overall evolution of the Canarian Archipelago. J. Volcanol. Geotherm. Res. 157, 271-293 (2006)

36. Amante, C. \& Eakins, B. W. ETOPO1 1 Arc-Minute Global Relief Model: Procedures, Data Sources and Analysis. NOAA Technical Memorandum NESDIS NGDC 24 (2009)

37. Baksi, A. K. Re-evaluation of plate motion models based on hotspot tracks in the Atlantic and Indian oceans. Journal of Geology 107, 13-26 (1999).

38. Baksi, A. K. in Plates, Plumes, and Planetary Processes (eds Foulger, G. \& Jurdy, D. M.) GSA special paper 430, 285-303 (2007).

\section{Acknowledgements}

I thank Claudia Benecke for moral support; Jan Sticklus for analytical support; and the Deutsche Forschungsgemeinschaft (DFG) for financial support (Project BO 912/8-1).

\section{Additional information}

Supplementary information accompanies this paper at http://www.nature.com/ scientificreports

Competing financial interests: The authors declare no competing financial interests.

How to cite this article: van den Bogaard, P. The origin of the Canary Island Seamount Province - New ages of old seamounts. Sci. Rep. 3, 2107; DOI:10.1038/srep02107 (2013)

(c) (1) $\Theta$ This work is licensed under a Creative Commons Attribution-

NonCommercial-NoDerivs 3.0 Unported license. To view a copy of this license, visit http://creativecommons.org/licenses/by-nc-nd/3.0 